\title{
Rendimiento y calidad de semilla de avena en función de la fecha y densidad de siembra*
}

\author{
Yield and quality of oat seed in function \\ of date and plant density
}

\begin{abstract}
Mirna Bobadilla Meléndez ${ }^{1}$, Alfredo J. Gámez Vázquez ${ }^{3}$, Miguel A. Ávila Perches ${ }^{1}$,Juan J. García Rodriguez ${ }^{1}$, Eduardo Espitia Rangel $^{3}$, Nicolás Moran Vázquez ${ }^{2}$ y Jorge Covarrubias Prieto ${ }^{2}$

${ }^{1}$ Campo Experimental Bajío- INIFAP. Carretera Celaya-San Miguel de Allende km 6.5, Colonia Roque, Celaya, Guanajuato, México. C.P. 38110. (avila.miguel@inifap. gob.mx; garcia.juan@inifap.gob.mx; gamez.josue@inifap.gob.mx; espitia.eduardo@inifap.gob.mx). ${ }^{2}$ Instituto Tecnológico de Roque. Carretera Celaya-Juventino Rosas, km 8. Colonia Roque, Celaya, Guanajuato, México. C.P. 38110 (quenimo_moran@yahoo.com.mx; covarrubiasjrg@hotmail.com). ${ }^{\S}$ Autor por correspondencia: bobadilla.mirna@inifap.gob.mx.
\end{abstract}

\section{Resumen}

El cultivo de avena tiene gran importancia en México, ya que se ha incrementado su superficie sembrada en los últimos 15 años. En años con retraso de temporal o con largos periodos de sequía, se ha promovido la siembra de este cereal en extensas áreas siniestradas; sin embargo, el abasto de semilla es insuficiente y su demanda es tan alta que propicia el comercio de semilla de dudosa calidad. En México aún no se dispone de la tecnología para el manejo agronómico adecuado hacia la producción de la misma. Por lo que el objetivo de estainvestigación fue evaluar el efecto de la fecha y densidad de siembra sobre el rendimiento, calidad física y fisiológica de la semilla de cuatro variedades, cultivadas en condiciones de riego en el Bajío guanajuatense, para lo cual se utilizó el diseño experimental de parcelas divididas. Las fechas de siembra fueron determinantes para la expresión del rendimiento y calidad física de semilla; sin embargo, no tuvieron influencia sobre las características fisiológicas, en la fecha más tardía (31 de diciembre) se obtuvo el mayor rendimiento, no obstante las condiciones ambientales de la misma influyeron desfavorablemente en el peso volumétrico. En la densidad de siembra de $90 \mathrm{~kg}$ de semilla ha ${ }^{-1}$ se obtuvo un buen rendimiento de semilla, peso volumétrico y peso de mil semillas. La constitución genética (variedades) mostró

\section{Abstract}

The oat crop has great importance in Mexico, as it has increased its area planted in the last 15 years. In years with rainfed delay or long periods of drought, has promoted the planting of this cereal in extensive disaster areas, however, the seed supply is insufficient and its demand is so high, that promotes the trade of dubious quality seed. In Mexico there is still no technology for proper agronomic management to the production thereof. So the objective of this research was to evaluate the effect of planting date and density on yield, physical and physiological quality of the seed of fourvarieties, grown under irrigation in the Bajío Guanajuato, for which was used a split plot design. Planting dates were crucial for the expression of yield and physical quality of seed; however did not affect the physiological characteristics, the late date (December 31) gave the highestyield, however environmental conditions thereof adversely influenced volumetric weight. In seed density of $90 \mathrm{~kg}$ seed ha ${ }^{-1}$ obtained a good yield, volumetric weight and thousand kernel weight. The genetic constitution (varieties) showed the greatest differential response among the factors studied, besides being crucial in the expression of physiological seed quality (germination percentage, length of plumule and seedling dry weight). The variety Obsidian was the best in yield and seed quality.

\footnotetext{
* Recibido: abril de 2013 
la mayor respuesta diferencial, entre los factores estudiados, además de haber sido determinante en la expresión de la calidad fisiológica de semilla (porcentaje de germinación, longitud de plúmula y peso seco de plántula). La variedad Obsidiana fue la mejor en rendimiento y calidad de semilla.

Palabras clave: Avena sativa L., manejo agronómico, peso volumétrico, germinación, vigor.

\section{Introducción}

En México, durante la década de los ochenta y mediados de los noventas, se sembraron entre $300 \mathrm{mil} \mathrm{y} 400 \mathrm{mil}$ ha de avena a nivel nacional y a partir de 1996 se incrementó la superficie cultivada, hasta alcanzar poco más de $900 \mathrm{mil}$ hectáreas en 2009 (SIAP, 2010). Este incremento se puede atribuir, entre otras cosas, a la adaptabilidad del cultivo, tanto a zonas altas, frías y lluviosas, como ambientes semiáridos; además, en altitudes mayores a $1800 \mathrm{msnm}$ es una alternativa apropiada cuando los cultivos de maíz, frijol, trigo o cebada se siniestran por sequía o por heladas tempranas (Villaseñor et al., 2008).

En México es la especie más utilizada para la reconversión productiva de las tierras de baja productividad donde la estación de crecimiento es corta, y el cambio climático requiere la siembra extensiva de especies rusticas, poco demandantes de agua y reducido ciclo biológico, como el cultivo de avena. Por lo anterior se requiere disponer de variedades aptas para la producción de forraje y grano con bondades agronómicas y fitopatológicas que permitan minimizar el efecto negativo de la roya del tallo [(Puccinia graminis f. sp. avenae) Erikss \& Hanning] y de la corona [(Puccinia coronata var. avenae) Fraser \& Ledingham]; así como de la ocurrencia de heladas tempranas y déficit hídrico intermitente (Villaseñor et al., 2003).

La roya del tallo es la enfermedad que más afecta a la producción de avena en México, debido a que se utilizan variedades altamente susceptibles como Chihuahua y Cuauhtémoc(Jiménez, 1992). Éste problema fitopatológico puede disminuir el rendimiento hasta $50 \%$ en estos genotipos (Leyva et al., 2004), especialmente importante en primaveraverano en la zona centro de México, razón por la cual estos ambientes pueden no ser adecuados para la producción de semilla y la producción en otoño-invierno en el Bajío mexicano se vuelve una opción.
Key words: Avena sativa L., agronomic management, volumetric weight, germination, vigor.

\section{Introduction}

In Mexico, during the eighties and mid-nineties, were planted between 300000 and 400000 ha of oat nationally and from 1996 acreage increased, reaching just over 900 000 hectares in 2009 (SIAP, 2010). This increase can be attributed, among other things, the adaptability of the crop, to highlands, cold and rainy, as semiarid environments; in addition, at altitudes greater than 1800 masl is an appropriate alternative when crops of corn, beans, wheat or barley are damaged by drought or early frost (Villaseñor et al., 2008).

In Mexico is the species most used for land reconversion of low productivity where the growing season is short, and climate change requires extensive planting of rustic species, water undemanding and reduced biological cycle, such as growing oat. Therefore, it is required to have suitable varieties for forage and grain production with agronomic and phytopathological benefits that minimize the negative effect of stem rust [(Puccinia graminis f. sp. Avenae) Erikss $\&$ Hanning] and crown [(Puccinia coronata var. avenae) Fraser \& Ledingham]; as well as the occurrence of early frost and intermittent water deficit (Villaseñor et al., 2003).

Stem rust is a disease that affects production of oat in Mexico, because highly susceptible varieties such as Cuauhtémoc and Chihuahua are used (Jiménez, 1992). This phytopathologic problem can decrease yield up to $50 \%$ in these genotypes (Leyva et al., 2004), especially important in spring and summer in the central area of Mexico, which is why these environments may not be suitable for seed production and autumn-winter production in the Mexican Bajío becomes an option.

During the last ten years, the National Institute of Research for Forestry, Agriculture and Livestock (INIFAP) has released oat varieties for rainfed crops with an increased forage and grain yield than those used traditionally and greater resistance to lodging. These new cultivars are early, drought and disease tolerant (Villaseñor et al., 2008). And even exceed in yield and tolerance to Chihuahua variety, it is important to define the production technology allowing to obtain seed quality for the market. 
Durante los últimos diez años, el Instituto Nacional de Investigaciones Forestales, Agrícolas y Pecuarias (INIFAP), ha liberado variedades de avena para siembras de temporal con mayor rendimiento de forraje y grano que las utilizadas tradicionalmente y, mayor resistencia al acame. Estos nuevos cultivares son precoces, tolerantes a sequía y enfermedades (Villaseñor et al., 2008). Y aunque superan en rendimiento y tolerancia a la variedad Chihuahua, es importante definir la tecnología de producción, que permita obtener semilla de calidad para el mercado.

En años donde se retrasan las lluvias o se prolongan los periodos de sequía inter o intraestival, el abasto de semilla de avena es insuficiente, lo que es crítico porque no se dispone de tecnología adecuada para la producción de la misma, nide la delimitación de ambientes con características favorables para la multiplicación de ésta.

La época de siembra define no solo el rendimiento y otros aspectos agronómicos del cultivo, sino también la expresión de algunos atributos de calidad, presencia o ausencia de organismos dañinos en la semilla, por lo que deberá seleccionarse cuidadosamente aquella que permita obtener los mejores rendimientos y calidad (Forsberg y Reeves, 1995). Se asocia con la duración del día, radiación solar y temperatura. Por lo que es importante identificar las zonas más adecuadas para el crecimiento, desarrollo y producción del cultivo. Por esta razón, la fecha óptima debe determinarse en cada localidad, lo que depende del clima y la incidencia de plagas yenfermedades(Berti etal.,2003) entre otros factores.

En trigo, se observó que la fecha de siembra influye sobre el rendimiento, registrándose los mayores rendimientos en fechas tempranas y conforme el establecimiento se retrasó, la producción tendía a disminuir; debido principalmente a la menor cantidad de horas frío recibidas por los genotipos (Ireta et al.,2007). Se ha observado también que en siembras tardías se acorta el ciclo vegetativo, así como el periodo reproductivo; afectándose el índice de área foliar; lo que produjo un decremento en la producción de biomasa, número de granos por unidad de superficie, peso del grano y por consiguiente el rendimiento(Solís et al.,2008). Por su parteAyala et al. (2006) observaron que la época de siembra influyó en el tamaño de la semillay por consiguiente en el peso volumétrico; sin embargo, las semillas más grandes no fueron las de mayor peso.

En un estudio realizado con cebada maltera, se determinó que las mejores fechas de siembra bajo condiciones de riego, estaban comprendidas durante el mes de diciembre,
In years where rains are delayed or prolonged periods of inter or dog days drought, the oat seed supply is insufficient, which is critical because there is no suitable technology for the production of the same, nor the delimitation of an environment with favorable characteristics for the multiplication of this.

Planting time defines not only the yield and other agronomic aspects of the crop, but also the expression of some quality attributes presence or absence of harmful organisms in the seed; so it should be carefully chosen that allowing to obtain the best yields and quality (Forsberg and Reeves, 1995). It is associated with day length, temperature and solar radiation. So it is important to identify the most suitable areas for growth, development and crop production. For this reason, the optimal date must be determined in each location, depending on the weather and the incidence of pests and diseases (Berti et al., 2003) among other factors.

In wheat, is observed that the planting date influences yield, recording higher yields at an early date and as the establishment is delayed, production tended to decrease, mainly due to the lesser amount of cold hours received by genotypes (Ireta et al., 2007). It has been observed that late sowing shortens the growth cycle and the reproductive period; thereby affecting the leaf area index, which produced a decrease in the production of biomass, number of grains per unit area, grain weight and therefore yield (Solís et al., 2008). Meanwhile Ayala et al. (2006) found that planting time influenced seed size and therefore the volumetric weight; however larger seeds were not heavier.

In a study of malting barley, was determined that the best planting dates under irrigation, were covered during the month of December, since it had a positive influence on two of the main components of yield and quality; these are number of grains per spike and thousand kernel weight (López et al., 2008). While the optimal planting time for oat seed production in the Bajío is reported ranging from November 20 to December 31 (García et al., 2008).

Plant density is an important factor in crop management from which depend to obtain high yields; high seeding doses cause less tillering, weak stems and prone to lodging, as well as increased demand for fertilizer. If not achieve an optimum density may be induced increases in production costs and lower yields (Solís et al., 2007). The seed vigor 
ya que influyen positivamente en dos de los principales componentes de rendimiento y calidad; estos son número de granos por espiga y peso de mil granos (López et al., 2008). Mientras que la época de siembra óptima para la producción de semilla de avena en el Bajío se reporta que va del 20 de noviembre al 31 de diciembre (García et al., 2008).

La densidad de siembra es un factor importante en el manejo del cultivo del que depende la obtención de altos rendimientos; altas dosis de siembra provocan un menor amacollamiento, tallos débiles y propensos al acame, además de mayor demanda de fertilizante. Si no se logra una densidad óptima se pueden inducir incrementos en los costos de producción y menores rendimientos (Solís et al., 2007). El vigor de la semilla es un factor que debe considerarse al momento de determinar la cantidad de semilla a utilizar, ya que como lo indican Braga et al. (2000), las de bajo vigor necesitan mayor densidad de población para obtener rendimientos similares a las semillas con alto vigor.

En trigo se ha observado que el rendimiento se incrementó a partir de 150 a 350 semillas por $\mathrm{m}^{2}$; con cantidades inferiores y superiores a éstas, la producción se reduce considerablemente; mientras que los mayores pesos de mil semillas se registraron en densidades menores y decreció al aumentar la cantidad de plantas por unidad de superficie (Kiliç y Gürsoy, 2010)

Ceccon et al. (2004), encontraron en avena que para la expresión del rendimiento de grano, número de panículas $\mathrm{m}^{-2}$ y peso de mil semillas, la densidad de plantas fue determinante e influyó positivamente; mientras que en el número de granos por panícula su efecto fue negativo.

Limón et al. (2010) mencionan que la dosis de siembra óptima para la producción de grano y forraje en avena, depende de una serie de factores y entre los más importantes se encuentran la calidad de la simiente y el método de siembra (mecánica y al voleo). Recomiendan utilizar 120 $\mathrm{kg} \mathrm{ha}^{-1}$ con semilla de buena calidad para obtener altos rendimientos.

Con base en lo anteriormente expuesto, en la presente investigación se planteó evaluar el rendimiento, la calidad física y fisiológica de la semilla de cuatro variedades de avena, sembradas en tres densidades de población y cuatro fechas de siembra. is a factor to be considered when determining the amount of seed to use, as indicated by Braga et al. (2000), the ones with low vigor need more density to obtain similar yields to those with high vigor.

In wheat has been observed that the yield increased from 150 to 350 seeds per $\mathrm{m}^{2}$, with lower and higher amounts to these, the production is greatly reduced, while higher thousand seed weights were recorded at lower densities and decreased to increase the number of plants per unit area (Kı1ıç and Gürsoy, 2010).

Ceccon et al. (2004) found in oat that for the expression of grain yield, number of panicles $\mathrm{m}^{-2}$ and thousand kernel weight, plant density was crucial and influenced positively; while the number of grains perpanicle its effect was negative.

Limón et al. (2010) mention that the optimum seeding rates for grain and forage production in oat, depends on a number of factors and among the most important are the quality of the seed and planting method (mechanical and broadcasting). They recommend using $120 \mathrm{~kg} \mathrm{ha}^{-1}$ with good seed quality to obtain high yields.

Based on the above, in the present study was planted to asses yield, physical and physiological quality of the seed from four varieties of oat, planted in three population densities and four planting dates.

\section{Materials and methods}

\section{Study area}

The study was conducted under irrigated conditions during the season autumn-winter 2008-2009, on land of the Bajío Experimental field(CEBAJ) from INIFAP, located in Roque, Celaya, Guanajuato $\left(20^{\circ} 35^{\prime} \mathrm{N}\right.$ and $\left.100^{\circ} 49^{\prime} \mathrm{N}\right)$ at 1756 masl with a semi warm climate, with temperatures ranging from $18^{\circ}$ to $22^{\circ} \mathrm{C}$, rainfall varies from 600 to $1000 \mathrm{~mm}$ per year, presenting an annual average of $670.3 \mathrm{~mm}$.

\section{Experimental design and management}

Four planting dates (FS) were established with intervals of approximately 15 days (November 15 and December 01, 15 and 31) denominated hereinafter also as FS 1, 2, 3 and 4 respectively. The experiment was established using a split 


\section{Materiales y métodos}

\section{Área de estudio}

El estudio se realizó bajo condiciones de riego durante el ciclo agrícola otoño-inviernos 2008-2009, en terrenos del Campo Experimental Bajío (CEBAJ) del INIFAP que se localiza en Roque, Celaya, Guanajuato $\left(20^{\circ} 35^{\prime}\right.$ latitud norte y $100^{\circ} 49^{\prime}$ latitud norte) a $1756 \mathrm{msnm}$, con un clima semicálido con temperaturas que van de $18^{\circ}$ a $22^{\circ} \mathrm{C}$, la precipitación pluvial varía de 600 hasta $1000 \mathrm{~mm}$ anuales, presentando un promedio anual de $670.3 \mathrm{~mm}$.

\section{Diseño experimental y manejo}

Se establecieron cuatro fechas de siembra (FS) con intervalos aproximados de 15 días ( 15 de noviembre, 1,15 y 31 de diciembre) en lo sucesivo se denominaran también como FS 1, 2, 3 y 4 respectivamente. El experimento se estableció mediante un diseño de parcelas divididas, con cuatro repeticiones; en la parcela grande se ubicaron cuatro genotipos: Menonita, Karma, Obsidiana y Chihuahua, mientras que en la parcela chica se colocaron tres densidades de siembra: 60, 90 y $120 \mathrm{~kg}$ de semilla ha-1. Es importante señalar que cada FS se consideró como un ambiente de evaluación.

La unidad experimental comprendió tres surcos de cinco metros de longitud distanciados a $0.75 \mathrm{~m}$, sembrados a doble hilera con una separación de $15 \mathrm{~cm}$ entre ellas. La parcelaútil fue el surco central. La fertilización empleada fue 75-40-00, se aplicó todo el fertilizante al momento de la siembra; el calendario de riegos se distribuyó de la siguiente manera: 0-45-80- 90 días después de la siembra.

\section{Variables evaluadas en campo}

La cosecha se realizó de manera mecánica con una trilladora experimental, se limpió la semilla de impurezas, se tomó su peso y humedad de grano; para posteriormente obtener el rendimiento de semilla(RS) de cada tratamiento, expresado en $\mathrm{tha}^{-1}$.

\section{Características determinadas en laboratorio}

En el laboratorio de semillas del CEBAJ se llevó a cabo la evaluación de la calidad física de la semilla mediante el peso volumétrico (PV) expresado en $\mathrm{kg} \mathrm{hL}^{-1}$, de acuerdo a plot design with four replications; in the largest plot were located four genotypes: Menonita, Karma, Obsidian and Chihuahua, while in the small plots were placed three seed densities: 60,90 and $120 \mathrm{~kg}$ of seed ha $^{-1}$. It is important to note that each FS was considered as a test environment.

The experimental unit consisted of three rows of five meters length spaced at $0.75 \mathrm{~m}$, planted in double rows with spacing of $15 \mathrm{~cm}$ between them. The useful plot was the central row. Fertilization used was 75-40-00, all the fertilizer was applied at the time of planting; the irrigation schedule was distributed as follows: 0 - 45 - 80 - 90 days after planting.

\section{Variables evaluated in field}

The harvest was made mechanically with an experimental thresher, seed was cleaned of impurities, recorded the weight and grain moisture; to subsequently obtain seed yield (RS) of each treatment, expressed in $\mathrm{tha}^{-1}$.

\section{Characteristics established in the laboratory}

In the CEBAJ seed laboratory was conducted the evaluation of the physical quality of the seed by the volumetric weight (PV) in $\mathrm{kg} \mathrm{hL}^{-1}$, according to the methodology proposed by Moreno (1996). Thousand kernels weight (PMS), was performed on a precision electronic scale recorded in grams.

The physiological quality was evaluated in the seed laboratory of the Division of Graduate Studies and Research Institute of Technology from Roque. To Determine the germination capacity was applied the methodology proposed by ISTA(2004), except the number of seeds, since 25 seeds from each of the treatments evaluated were used, which were placed with the embryo axis upright and radicle down on a line in the central part of a wet paper towel, used as a substrate that was coated with other similar, which rolled in a "taco" and covered with polyethylene, then positioned vertically inside a Revco germination chamber (R1-12-1060-ABA) at a temperature of $20^{\circ} \mathrm{C} \pm 1{ }^{\circ} \mathrm{C}$ for a period of six days. After this period the normal, abnormal seedlings and dead seeds were evaluated. The determination of the standard germination percentage (GE) was performed based on the average of normal seedlings.

Furthermore, to determine the length of plumule standard germination (LPGE), was assessed the overall length of the plumules of normal seedlings coming from the 
la metodología propuesta por Moreno (1996). El peso de mil semillas (PMS), se realizó en una báscula electrónica de precisión registrándose en gramos.

La calidad fisiológica se evaluó en el laboratorio de semillas de la División de Estudios de Posgrado e Investigación del Instituto Tecnológico de Roque. Para determinar la capacidad germinativa se aplicó la metodología propuesta por ISTA (2004), a excepción del número de semillas, ya que se utilizaron 25 semillas de cada uno de los tratamientos evaluados, que se colocaron con el eje embrionario en posición vertical y la radícula hacia abajo sobre una línea trazada en la parte central de una toalla de papel húmedo utilizado como sustrato que fue cubierto con otro similar, que se enrollaron en forma de "taco" y se cubrieron con polietileno, para después colocarse en posición vertical dentro de una cámara germinadora Revco (R1-12-1060ABA) a una temperatura de $20^{\circ} \mathrm{C} \pm 1{ }^{\circ} \mathrm{C}$ por un periodo de seis días. Después de este período se evaluaron las plántulas normales, anormales y semillas muertas. La determinación del porcentaje de germinación estándar (GE) se realizó en base al promedio de plántulas normales.

Además, para determinar la longitud de plúmula de germinación estándar (LPGE), se evaluó el largo total de las plúmulas de las plántulas normales provenientes de la prueba de germinación estándar, se registró el promedio de las mediciones que se reportó en centímetros. Asimismo, para evaluar el peso seco de plántula de germinación estándar (PSPGE), después de la evaluación de la germinación y longitud de plúmula, las plántulas normales se separaron del resto de la semilla y se sometieron a secado en estufa marca Felisa (FE-143AD) a $70{ }^{\circ} \mathrm{C}$ por $48 \mathrm{~h}$, posteriormente se pesaron en una balanza analítica de precisión $(0.0001$ $\mathrm{g}$ ), para lo cual el peso seco total se dividió entre el número total de plántulas normales, registrándose el peso seco en miligramos por plántula.

Para efectuar el ensayo de envejecimiento acelerado, se utilizaron 25 semillas por cada uno de los tratamientos evaluados, para lo cual se utilizaron cajas de plástico de 13 $\mathrm{x} 13 \mathrm{x} 4 \mathrm{~cm}$ con $100 \mathrm{ml}$ de agua y una malla de alambre de $0.5 \times 0.5 \mathrm{~cm}$ colocada en la parte media de la caja, sobre la que se pusieron las simientes a evaluar, con el propósito de que estas no estuvieran en contacto con el agua. Las cajas se taparon, se colocaron en una cámara, se sometieron a una temperatura de $42 \pm 1{ }^{\circ} \mathrm{C}$ y alrededor de $100 \%$ de humedad relativa durante $48 \mathrm{~h}$. Al término del período de estrés, se sacaron las semillas y se realizó una prueba para estimar standard germination test, recorded the average from the measurements which was reported in centimeters. Also, to evaluate the seedling dry weight of standard germination (PSPGE), after the evaluation of germination and length plumule, normal seedlings were separated from the rest of the seed, and subjected to drying in an oven Felisa (FE- 143AD) at $70^{\circ} \mathrm{C}$ for $48 \mathrm{~h}$, and then weighed on a precision analytical scale $(0.0001 \mathrm{~g})$, for which the total dry weight was divided by the total number of normal seedlings, recording the dry weight in milligrams per seedling.

To perform the accelerated aging test, 25 seeds were used for each of the treatments evaluated, for which were used plastic boxes of $13 \times 13 \times 4 \mathrm{~cm}$ with $100 \mathrm{ml}$ of water and a wire mesh of $0.5 \times 0.5 \mathrm{~cm}$ placed in the middle of the box, on the seeds that were evaluated, in order that these were not in contact with water. The boxes were covered, placed in a chamber, subjected to a temperature of $42 \pm 1{ }^{\circ} \mathrm{C}$ and about $100 \%$ relative humidity for $48 \mathrm{~h}$. At the end of the stress period, the seeds were removed and performed a test to estimate the germination capacity according to ISTA(2004), were determined the following characteristics: germination (GEA), length of plumule (LPGEA) and dry weight of seedling after accelerated aging (PSPEA), for which was followed the methodology described above.

\section{Statistical analysis}

The data obtained in the evaluation were analyzed with the Statistical Analysis System program and for variables that showed statistically significant differences was used the Tukey test, $p<0.05$ (SAS, 2003).

\section{Results and discussion}

\section{Seed yield and physical quality}

The analysis of variance (Table 1), combined the four evaluation environments showing significant differences $(p \leq 0.01)$ between the FS in terms of yield and volumetric weight which means that under the conditions in which the experiment was conducted, these were affected by the environmental conditions prevailing during the planting; this result was expected due to the existing environmental variations and information about other experiences, which proved the objective to analyze the effect of FS on production and seed quality. 
la capacidad germinativa de acuerdo con ISTA (2004), donde se determinaron las siguientes características: germinación (GEA), longitud de plúmula (LPGEA) y peso seco de plántula después de envejecimiento acelerado (PSPEA), para lo cual se siguió la metodología descrita anteriormente.

\section{Análisis estadístico}

Los datos obtenidos en la evaluación fueron analizados con el programa Statistical Analysis System y para las variables que mostraron diferencias estadísticamente significativas se realizó la prueba de comparación de medias de Tukey, $p \leq 0.05$ (SAS, 2003).

\section{Resultados y discusión}

\section{Rendimiento de semilla y calidad física}

El análisis de varianza (Cuadro 1), combinado de los cuatro ambientes de evaluación, mostró diferencias significativas $(p \leq 0.01)$ entre las FS en cuanto al rendimiento y peso volumétrico lo que significa que bajo las condiciones en las que se llevó a cabo este experimento, éstos fueron afectados por las condiciones ambientes prevalecientes durante las épocas de siembra; se esperaba este resultados debido a las variaciones ambientales existentes y a la información sobre otras experiencias, lo cual comprobó el objetivo de analizar el efecto de la FS sobre la producción y calidad de la semilla.

Las variedades (V) fueron el factor que tuvo el mayor número de diferencias en las variables de productividad y calidad física evaluadas, lo que nos señala que estas diferencias estadísticas entre ellas se deben a su constitución genética; cumple con el objetivo de identificar la variedad más productiva. Mientras que las densidades de siembra (DS) permitieron observar diferencias estadísticas ( $p \leq$ 0.01 ) en el rendimiento y peso volumétrico y al $p \leq 0.05$ en el peso de mil semillas; la densidad de población es un factor importante para incrementar los rendimientos unitarios; la comparación de medias nos permitirá determinar cuál es la más adecuada sin que se presente un techo en la respuesta; esto nos muestra que hay una respuesta diferencial debido a las diferentes cantidades de semilla que se emplearon en la evaluación.
The varieties $(\mathrm{V})$ was the factor that had the greatest number of differences in variables of productivity and physical quality, which tells us that these statistical differences among them are due to their genetic makeup; meets the objective of identifying the most productive variety. While seeding (DS) allowed to observe statistical differences $(p \leq 0.01)$ in yield and volumetric weight and $p \leq 0.05$ in thousand kernel weight; plant density is an important factor to increase the yield per unit; comparison of mean allows us to determine which is the most adequate without having apeak present in the response, this shows that there is a differential response due to different amounts of seed that were used in the evaluation.

The comparison of means by Tukey test $p \leq 0.05$ (Table 2 ) indicates that the planting date of December 31 obtained the highest yield average, statistically different from the other dates, with $3.99 \mathrm{tha}^{-1}$; while the sowing dates of December 01 and November 15 were statistically equal; the date of December 15 showed the least favorable conditions for the production of seed $\left(2.74 \mathrm{tha}^{-1}\right)$; this result indicates that as the planting date forwards, the environmental conditions are unfavorable for production due to the lower amount of cold hours that the genotypes receive, coinciding with Iretas et al. (2007). Overall, the sowing dates from December favorably influenced yield; this behavior was similar to the result obtained in malting barley by López et al. (2008).

Regarding the volumetric weight, the best behavior was obtained by the FS from December 01 showing the highest average with $46.19 \mathrm{~kg} \mathrm{hL}^{-1}$. The value of this attribute is dependent on the density and physical characteristics of the seed (width and thickness); also associated with solid and heavy seed. The late planting dates showed a negative influence on PV, as it recorded the lowest weights; this decrease was due to the temperatures present during the period of flowering to physiological maturity, which affected the size and weight of seed, so that the PV was affected; coinciding with that obtained by Valenzuela et al. (1995). The FS ofDecember 31 had the lowest PV (Table 2).

The comparison of varieties shows that the variety Obsidian was the most productive with an average yield of $3.79 \mathrm{t}$ $\mathrm{ha}^{-1}$, coinciding with those obtained by Leyva et al. (2004); followed in importance Karma and Chihuahua, Menonita possibly by being an early variety was the one that showed the lowest value (Table 3 ). 
Cuadro 1. Cuadrados medios y nivel de significancia estadística del análisis de varianza, de rendimiento y calidad física de semilla en cuatro variedades de avena, cuatro fechas y tres densidades de siembra. Celaya, Guanajuato.

Table 1. Mean squares and statistical significance level from the analysis of variance, for yield and physical quality of seed in four varieties of oat, four dates and three plant densities. Celaya, Guanajuato.

\begin{tabular}{|c|c|c|c|c|c|c|}
\hline Fuente de variación & \multicolumn{2}{|c|}{ Rendimiento } & \multicolumn{2}{|c|}{ Peso volumétrico } & \multicolumn{2}{|c|}{ Peso de 1000 semillas } \\
\hline FS & 12.480 & $* *$ & 115.26 & $* *$ & 13.95 & \\
\hline Rep (FS) & 0.751 & & 4.26 & & 16.27 & \\
\hline V & 7.550 & $* *$ & 258.13 & ** & 184.14 & $* *$ \\
\hline $\mathrm{FS} * \mathrm{~V}$ & 0.610 & $* *$ & 8.89 & $*$ & 44.83 & $* *$ \\
\hline Error a & 0.130 & & 3.52 & & 15.05 & \\
\hline $\mathrm{DS}$ & 0.680 & ** & 12.42 & $* *$ & 65.44 & * \\
\hline $\mathrm{FS} * \mathrm{DS}$ & 0.137 & & 3.05 & & 17.82 & \\
\hline V*DS & 0.185 & & 5.13 & $*$ & 20.79 & \\
\hline $\mathrm{FS} * \mathrm{~V} * \mathrm{DS}$ & 0.105 & & 1.34 & & 11.55 & \\
\hline Error b & 0.107 & & 2.17 & & 19.51 & \\
\hline $\operatorname{CV}(\%)^{*}$ & 9.742 & & 3.32 & & 12.17 & \\
\hline
\end{tabular}

*,** Significativo al 0.05 y 0.01 niveles de probabilidad respectivamente; ${ }^{*} \mathrm{CV}=$ coeficiente de variación; $\mathrm{FS}=$ fecha de siembra; $\mathrm{V}=$ variedad; $\mathrm{DS}=$ densidad de siembra; Rep= repeticiones.

La comparación de medias mediante la prueba de Tukey $p \leq 0.05$ (Cuadro 2) nos indica que la fecha de siembra del 31 de diciembre obtuvo el rendimiento promedio más alto, estadísticamente diferente a las otras fechas, con $3.99 \mathrm{t} \mathrm{ha}^{-1}$, mientras que la fechas de siembras del 01 de diciembre y 15 de noviembre fueron estadísticamente iguales; la fecha del 15 de diciembre mostró las condiciones menos favorables para la producción de simiente $\left(2.74 \mathrm{tha}^{-1}\right)$; éste resultado nos indica que a medida que se adelanta la fecha de siembra, las condiciones ambientales son desfavorables para la producción debido a la menor cantidad de horas frío que recibieron los genotipos coincidiendo con Ireta et al. (2007). En general, las fechas de siembra de diciembre influyeron favorablemente en el rendimiento; este comportamiento fue similar al resultado obtenido en cebada maltera por López et al. (2008).

En cuanto al peso volumétrico el mejor comportamiento lo obtuvo la FS del 01 de diciembre mostrando el mayor promedio con $46.19 \mathrm{~kg} \mathrm{hL}^{-1}$. El valor de este atributo está en función de la densidad y características físicas de la semilla (anchura y espesor); además, está asociado con semillas sólidas y pesadas. Las fechas de siembra tardías mostraron una influencia negativa en el PV, ya que se registraron los pesos más bajos; esta disminución se debióa las temperaturas que se presentan durante el periodo de floración a madurez fisiológica, lo que repercutió en el tamaño y peso de la semilla, por lo que el PV se vio afectado; coincidiendo con lo obtenido por Valenzuela et al. (1995). La FS del 31 de diciembre obtuvo el menor PV (Cuadro 2).
Cuadro 2. Comparación de medias del rendimiento y calidad física de cuatro variedades de avena, establecidas en fechas de siembra. Celaya, Guanajuato. Otoño-invierno, 2008-2009.

Table 2. Comparison of means of yield and physical quality from four varieties of oat established in planting dates. Celaya, Guanajuato. Autumn-Winter, 2008-2009.

\begin{tabular}{ccc}
\hline $\begin{array}{c}\text { Fecha de } \\
\text { siembra }\end{array}$ & $\begin{array}{c}\text { Rendimiento } \\
\left(\mathrm{t} \mathrm{ha}^{-1}\right)\end{array}$ & $\begin{array}{c}\text { Peso volumétrico } \\
\left(\mathrm{kg} \mathrm{hL}^{-1}\right)\end{array}$ \\
\hline 31-dic.-08 & $3.99 \mathrm{a}$ & $42.63 \mathrm{c}$ \\
01-dic.-08 & $3.37 \mathrm{~b}$ & $46.19 \mathrm{a}$ \\
15-nov.-08 & $3.35 \mathrm{~b}$ & $44.91 \mathrm{~b}$ \\
15-dic.-08 & $2.74 \mathrm{c}$ & $43.62 \mathrm{c}$ \\
\hline Valores con la misma letra son estadísticamente iguales, según Tukey $(p \leq 0.05)$.
\end{tabular}

Regarding the varieties (Table 3) the highest volumetric weight from spring-summer had it Menonita and Obsidian with $46.48 \mathrm{~kg} \mathrm{hL}^{-1}$ and $45.75 \mathrm{~kg} \mathrm{hL}^{-1}$ respectively; while the lowest value was for Chihuahua with $41.28 \mathrm{~kg} \mathrm{hL}^{-1}$; the PV is related to grain density and thus with texture of the endosperm or with protein content and health condition thereof. In the thousand kernel weight, the best response was obtained by the variety Obsidian with $38.34 \mathrm{~g}$; however, was statistically equal to Chihuahua; the lowest weight was recorded in Menonita with 33.78 g. These results indicate that probably the seeds of the variety Menonita are smaller than that of other varieties due to its early cycle; allowing, accommodating better in 
En la comparación de variedades se observa que la variedad Obsidiana fue la más productiva con un rendimiento de semilla promedio de $3.79 \mathrm{tha}^{-1}$, coincidiendo con lo obtenido por Leyva et al. (2004); le siguió en importancia Karma y Chihuahua, Menonita posiblemente por ser una variedad precoz fue la que mostró el menor valor (Cuadro 3).

Respecto a las variedades (Cuadro 3) el mayor primaveraverano lo obtuvieron Menonita y Obsidiana con $46.48 \mathrm{~kg}$ $\mathrm{hL}^{-1}$ y $45.75 \mathrm{~kg} \mathrm{hL}^{-1}$ respectivamente; el menor valor fue para Chihuahua con $41.28 \mathrm{~kg} \mathrm{hL}^{-1}$; el PV se relaciona con la densidad del granoy por lo tanto con la textura del endospermo o con el contenido de proteína y estado de salud del mismo. En el peso de mil semillas, la mejor respuesta la obtuvo la variedad Obsidiana con $38.34 \mathrm{~g}$; sin embargo, fue estadísticamente igual a Chihuahua; el menor peso fue registrado en Menonita con 33.78 g. Éstos resultados nos indican que probablemente las semillas de las variedad Menonita por su ciclo precoz es más pequeña que la del resto de las variedades, permitiéndole, acomodarse de mejor manera en el recipiente al momento de dejarla caer de manera libre, evitando espacios libres entre las semillas, lo cual coincide con Ayala et al. (2006) y GutiérrezGarcía et al. (2006).

Las densidades de siembra de 120 y $90 \mathrm{~kg}$ de semilla ha ${ }^{-1}$ (Cuadro 4) mostraron el mayor rendimiento promedio de $3.42 \mathrm{t} \mathrm{ha}^{-1}$; esto nos indica que a mayor densidad mayor rendimiento coincidiendo con Rivera-Reyes et al. (2008)y Medina et al. (2009) la influencia de la densidad de siembra sobre el rendimiento de grano a través del aumento de la producción de espigas por unidad de área, lo que coincide con Turk et al. (2003); sin embargo, se redujo el peso de mil semillas, lo que coincide con los resultados obtenidos por Ceccon et al. (2004), así como en trigo por Kiliç y Gürsoy (2010) y en cebada por González et al. (1993). En este sentido, el utilizar una densidad de población de 90 $\mathrm{kg} \mathrm{ha} \mathrm{h}^{-1}$ permitiría reducir la recomendación tradicional en $10 \mathrm{~kg}$ por unidad de superficie, lo que representa a su vez un ahorro en los costos de producción y por lo tanto una posibilidad de mejorar la rentabilidad del proceso de producción de semilla.

Estas mismas densidades obtuvieron el promedio más alto en cuanto al primavera- verano con 44.78 y $44.34 \mathrm{~kg} \mathrm{hL}^{-1}$ respectivamente y la de menor peso fue la densidad de 60 $\mathrm{kg} \mathrm{ha}^{-1}$ con $43.90 \mathrm{~kg} \mathrm{hL}^{-1}$; se observa que a mayor densidad se presentó un incremento en el peso; caso contrario en lo que respecta al peso de mil semillas en donde se observa que a medida que aumenta la densidad de población, como the container when dropping freely, avoiding gaps between the seeds, which coincides with Ayala et al. (2006) and Gutiérrez-García et al. (2006).

Cuadro 3. Comparación de medias del rendimiento y calidad física evaluadas en cuatro variedades de avena. Celaya, Guanajuato.

Table 3. Comparison of means of yield and physical quality evaluated in four varieties of oat. Celaya, Guanajuato.

\begin{tabular}{cccc}
\hline Variedad & $\begin{array}{c}\text { Rendimiento Peso volumétrico Peso de } 1000 \\
\left(\mathrm{t} \mathrm{ha}^{-1}\right)\end{array}$ & $\begin{array}{c}\left(\mathrm{kg} \mathrm{hL}^{-1}\right) \\
\text { semillas }(\mathrm{g})\end{array}$ \\
\hline Obsidiana & $3.79 \mathrm{a}$ & $45.75 \mathrm{a}$ & $38.34 \mathrm{a}$ \\
Karma & $3.50 \mathrm{~b}$ & $43.85 \mathrm{~b}$ & $35.83 \mathrm{~b} \mathrm{c}$ \\
Chihuahua & $3.31 \mathrm{~b}$ & $41.28 \mathrm{c}$ & $37.23 \mathrm{a} \mathrm{b}$ \\
Menonita & $2.84 \mathrm{c}$ & $46.48 \mathrm{a}$ & $33.80 \mathrm{c}$ \\
\hline
\end{tabular}

Valores con la misma letra son estadísticamente iguales, según Tukey $(p \leq 0.05)$.

Planting densities of 120 and $90 \mathrm{~kg}$ seed ha ${ }^{-1}$ (Table 4 ) showed the highest average yield of $3.42 \mathrm{t} \mathrm{ha}^{-1}$; this indicates that a higher density a higher yield coinciding with Rivera-Reyes et al. (2008) and Medina et al. (2009) the effect of plant density on grain yield through the increase of production of ears per unit area, which coincides with Turk et al. (2003); however, the thousand kernel weight was reduced, which is consistent with the results obtained by Ceccon et al.(2004), as well as in wheat by Kiliç and Gürsoy (2010) and in barley by González et al. (1993). In this sense, the use of plant density of $90 \mathrm{~kg}$ $\mathrm{ha}^{-1}$ would allow reducing the traditional recommendation in $10 \mathrm{~kg}$ per unit area, which in turn represents a saving in production costs and therefore a possibility to improve profitability of seed production process.

These same densities obtained the highest average related to the spring-summer cycle with 44.78 and $44.34 \mathrm{~kg} \mathrm{hL}^{-1}$ respectively and the lowest weight had it the density 60 $\mathrm{kg} \mathrm{ha}^{-1}$ with $43.90 \mathrm{~kg} \mathrm{hL}^{-1}$; it is observed that the higher the density there was an increase in weight; contrary to the thousand kernel weight where it is observed that as the population density increases, as expected, the seed weight decreases, due to the competitive effect and such effect was observed in the density of $60 \mathrm{~kg} \mathrm{ha}^{-1}$ that had larger seed which had the highest average with $37.46 \mathrm{~g}$ and the density of $120 \mathrm{~kg} \mathrm{ha}^{-1}$ the lowest weight with $35.66 \mathrm{~g}$, coinciding this behavior with Rivera-Reyes et al. (2008) and Gámez et al. (2007), who obtained similar results. This indicates that large seeds tend to have more free space between the seeds 
se esperaba, el peso de la semilla disminuye, por efecto de competencia y tal efecto se observó en la densidad de $60 \mathrm{~kg} \mathrm{ha}^{-1}$ que tuvo semilla de mayor tamaño la cual obtuvo el mayor promedio con $37.46 \mathrm{~g}$ y la densidad de $120 \mathrm{~kg} \mathrm{ha}^{-1}$ el menor peso con $35.66 \mathrm{~g}$, coincidiendo este comportamiento con Rivera-Reyes et al. (2008) y Gámez et al. (2007), quienes obtuvieron resultados similares. Esto nos indica que semillas grandes tienden a tener mayor espacio libre entre las semillas al momento de realizar la prueba de peso volumétrico, situación que también fue reportada por Ayala et al. (2006) y Gutiérrez-García et al. (2006).

\section{Calidad fisiológica}

Los resultados del análisis de varianza (Cuadro 5) de los componentes de calidad fisiológica de semilla de avena mostraron diferencia altamente significativa $(p \leq 0.01)$ entre las variedades en casi todas las variables evaluadas excepto en longitud de plúmula con el tratamiento de envejecimiento acelerado donde la probabilidad de la diferencia estadística fue menor $(p \leq 0.05)$. El porcentaje de germinación mostró significancia $(p \leq 0.05)$ en la triple interacción. at the time of testing volumetric weight, a situation which was also reported by Ayala et al. (2006) and Gutiérrez-García et al. (2006).

Cuadro 4. Comparación de medias del rendimiento y calidad física evaluadas en cuatro variedades de avena, bajo tres densidades de siembra. Celaya, Guanajuato.

Table 4. Comparison of means of yield and physical quality evaluated in four varieties of oat, under three plant densities. Celaya, Guanajuato.

\begin{tabular}{cccc}
\hline $\begin{array}{c}\text { Densidad de } \\
\text { siembra }\left(\mathrm{kg} \mathrm{ha}^{-1}\right)\end{array}$ & $\begin{array}{c}\text { Rendimiento } \\
\left(\mathrm{t} \mathrm{ha}^{-1}\right)\end{array}$ & $\begin{array}{c}\text { Peso } \\
\text { volumétrico } \\
\left(\mathrm{kg} \mathrm{hL}^{-1}\right)\end{array}$ & $\begin{array}{c}\text { Peso de } \\
1000 \\
\text { semillas }(\mathrm{g})\end{array}$ \\
\hline 120 & $3.42 \mathrm{a}$ & $44.78 \mathrm{a}$ & $35.66 \mathrm{a}$ \\
90 & $3.42 \mathrm{a}$ & $44.34 \mathrm{a} \mathrm{b}$ & $35.78 \mathrm{a}$ \\
60 & $3.24 \mathrm{~b}$ & $43.90 \mathrm{~b}$ & $37.46 \mathrm{a}$ \\
\hline
\end{tabular}

Valores con la misma letra son estadísticamente iguales, según Tukey $(p \leq 0.05)$.

\section{Physiological quality}

The results of the analysis of variance (Table 5) from the components of the physiological quality of oat seed, showed highly significant difference $(p \leq 0.01)$ between the varieties

Cuadro 5. Cuadrados medios, grados de libertad y nivel de significancia estadística del análisis de varianza, en las variables de calidad fisiológica evaluadas en semilla de avena, sin y después de envejecimiento acelerado. Celaya, Guanajuato.

Table 5. Mean squares, degrees of freedom and level of statistical significance of the analysis of variance, in variables of physiological quality evaluated in oat seed, without and after accelerated aging. Celaya, Guanajuato.

\begin{tabular}{|c|c|c|c|c|c|c|c|c|c|c|c|c|}
\hline \multirow{2}{*}{$\begin{array}{l}\text { Fuente de } \\
\text { variación }\end{array}$} & \multicolumn{6}{|c|}{ Sin envejecimiento acelerado } & \multicolumn{6}{|c|}{ Después de envejecimiento acelerado } \\
\hline & GE & & LPGE & & PSPGE & & GEA & & LPGEA & & PSPEA & \\
\hline FS & 11.86 & & 1.52 & & 1.23 & & 440.22 & & 1.57 & & 3.27 & \\
\hline $\operatorname{Rep}(\mathrm{FS})$ & 31.08 & & 9.57 & & 25.30 & & 1754.06 & & 3.85 & & 21.08 & \\
\hline $\mathrm{V}$ & 61.42 & $* *$ & 9.67 & $* *$ & 95.83 & $* *$ & 4400.89 & $* *$ & 5.64 & $*$ & 50.43 & $* *$ \\
\hline $\mathrm{FS} * \mathrm{~V}$ & 31.94 & & 0.43 & & 1.06 & & 305.56 & & 1.29 & & 1.82 & \\
\hline Error a & 15.23 & & 0.32 & & 0.61 & & 206.28 & & 1.53 & & 3.05 & \\
\hline DS & 12.33 & & 0.27 & & 0.91 & & 130.08 & & 0.13 & & 2.22 & \\
\hline $\mathrm{FS} * \mathrm{DS}$ & 19.11 & & 0.35 & & 0.85 & & 276.97 & & 0.43 & & 2.46 & \\
\hline $\mathrm{V}^{*} \mathrm{DS}$ & 8.00 & & 0.58 & & 0.42 & & 220.64 & & 0.87 & & 1.92 & \\
\hline $\mathrm{FS} * \mathrm{~V} * \mathrm{DS}$ & 14.63 & & 0.40 & & 0.66 & & 359.53 & $*$ & 0.81 & & 2.38 & \\
\hline Error b & 14.19 & & 0.35 & & 0.47 & & 202.89 & & 1.23 & & 2.53 & \\
\hline $\mathrm{CV}(\%)$ & 3.90 & & 6.87 & & 6.25 & & 22.06 & & 13.53 & & 15.78 & \\
\hline
\end{tabular}

*,** Significativo al 0.05 y 0.01 niveles de probabilidad respectivamente. ${ }^{\star} \mathrm{CV}=$ coeficiente de variación; $\mathrm{FS}=$ fecha de siembra; $\mathrm{V}=\mathrm{variedad} ; \mathrm{DS}=\mathrm{densidad} \mathrm{de}$ siembra; Rep= repeticiones; $\mathrm{GE}=$ germinación estándar; $\mathrm{LPGE}=$ longitud de plántula de germinación estándar; PSPGE= peso seco de plántula de germinación estándar; GEA= germinación después de envejecimiento acelerado; LPGEA= longitud de plántula de germinación con envejecimiento acelerado; PSPEA= pesos seco de plántula con envejecimiento acelerado. 
Al realizar la comparación de medias (Cuadro 6) la GE fue mayor en Menonita y Obsidiana, ambas con $97.25 \%$, el porcentaje menor lo obtuvo la variedad Chihuahua 94.92\%; Obsidiana mostró el valor más alto en LPGE y PSPGE con $9.13 \mathrm{~cm}$ y $12.28 \mathrm{mg}$ plántula $^{-1}$; en estas variables los promedio más bajos se registraron en Karma $(8.08 \mathrm{~cm})$ y Menonita (9.59 $\left.\mathrm{mg}_{\text {plántula }}{ }^{-1}\right)$ respectivamente.

Con el tratamiento de envejecimiento acelerado, la GEA fue estadísticamente igual en Menonita (71.08), Obsidiana $(70.42 \%)$ y Karma $(66.25 \%)$. En la variable LPGEA presentaron un valor mayor a $8.1 \mathrm{~cm}$, mientras que en Chihuahua fue menor a $7.8 \mathrm{~cm}$. En la variable PSPEA, Menonita mostró el valor más bajo ( $8.8 \mathrm{mg}_{\text {plántula }}{ }^{-1}$ ), mientras que, Obsidiana y Chihuahua obtuvieron el mayor peso. Se observa además, que la variedad Chihuahua, fue la más afectada por el tratamiento, pues se redujo en mayor proporción la germinación; Karma no tuvo ninguna reducción en peso seco de plántula y en longitud de plúmula entre los dos tratamientos (sin y con envejecimiento); sólo mostró reducción en la germinación. in almost all variables except in the length of plumule with the accelerated aging treatment where the probability of statistical difference was lower $(p \leq 0.05)$. The germination percentage showed significance $(p \leq 0.05)$ in the triple interaction.

When comparing means (Table 6) GE was higher in Menonita and Obsidian, both with $97.25 \%$, the lowest percentage was obtained by the variety Chihuahua 94.92\%; Obsidian showed the highest value in LPGE and PSPGE with $9.13 \mathrm{~cm}$ and $12.28 \mathrm{mg}$ seedling ${ }^{-1}$, in these variables the lowest average were recorded in Karma $(8.08 \mathrm{~cm})$ and Menonita (9.59 $\mathrm{mg}$ seedling $^{-1}$ ) respectively.

With the accelerated aging treatment, the GEA was statistically equal in Menonita (71.08), Obsidian (70.42\%) and Karma $(66.25 \%)$. The variable LPGEA showed a value greater than $8.1 \mathrm{~cm}$, while in Chihuahua was less than $7.8 \mathrm{~cm}$. In the variable PSPEA, Menonita showed the lowest value (8.8 $\mathrm{mg}$ seedling $^{-1}$ ), while Obsidian and Chihuahua had the highest weight. It is also noted that the variety Chihuahua,

Cuadro 6. Comparación de medias de las variables de calidad fisiológica evaluadas en semilla de cuatro variedades de avena, establecidas bajo tres densidades de siembra y en cuatro fechas. Celaya, Guanajuato.

Table 6. Comparison of means of variable physiological quality evaluated in seed of four varieties of oat, established under three plant densities and four dates. Celaya, Guanajuato.

\begin{tabular}{|c|c|c|c|c|c|c|c|c|c|c|c|c|}
\hline \multirow{3}{*}{$\begin{array}{l}\text { Variedades } \\
\text { Menonita }\end{array}$} & \multicolumn{6}{|c|}{ Sin envejecimiento } & \multicolumn{6}{|c|}{ Después de envejecimiento acelerado } \\
\hline & \multicolumn{2}{|c|}{$\mathrm{GE}(\%)$} & \multicolumn{2}{|c|}{$\operatorname{LPGE}(\mathrm{cm})$} & \multicolumn{2}{|c|}{ PSPGE (mg) } & \multicolumn{2}{|c|}{$\operatorname{GEA}(\%)$} & \multicolumn{2}{|c|}{$\operatorname{LPGEA}(\mathrm{cm})$} & \multicolumn{2}{|c|}{ PSPEA (mg) } \\
\hline & 97.25 & $\mathrm{a}$ & 8.563 & $\mathrm{~b}$ & 9.594 & $\mathrm{~b}$ & 71.08 & $\mathrm{a}$ & 8.25 & $\mathrm{ab}$ & 8.80 & $\mathrm{c}$ \\
\hline Obsidiana & 97.25 & $\mathrm{a}$ & 9.125 & $\mathrm{a}$ & 12.28 & $\mathrm{a}$ & 70.42 & $\mathrm{a}$ & 8.15 & $a b$ & 11.24 & $\mathrm{a}$ \\
\hline Karma & 97.00 & $a b$ & 8.083 & $\mathrm{c}$ & 9.861 & $\mathrm{~b}$ & 66.25 & $\mathrm{a}$ & 8.60 & $\mathrm{a}$ & 9.84 & $\mathrm{~b}$ \\
\hline Chihuahua & 94.92 & $\mathrm{~b}$ & 8.875 & $\mathrm{a}$ & 12.044 & $\mathrm{a}$ & 50.58 & b & 7.77 & b & 10.41 & $a b$ \\
\hline
\end{tabular}

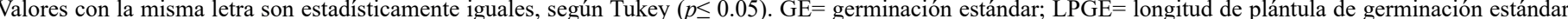

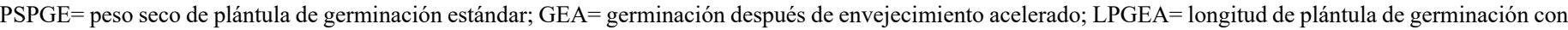
envejecimiento acelerado; PSPEA= pesos seco de plántula con envejecimiento acelerado.

Encuanto al tamaño y peso de las semillas, existe controversia del efecto de este atributo sobre la capacidad germinativa y vigor; esta se basa en evidencias que establecen que semillas grandes y pesadas son más vigorosas. Las semillas grandes y pesadas tienen ventajas en el proceso de germinación y en la emergencia en comparación con las semillas más pequeñas; semillas más grandes desarrollan una mayor plúmula y raíz, debido a un mayor endospermo y a una mayor cantidad de nutrientes. En la presente investigación se observó que la variedad con un comportamiento consistente entre la calidad física y fisiológica, lo mostró Obsidiana con un buen peso was the most affected by the treatment, because the germination was reduced in greater proportion; Karma had no reduction in seedling dry weight and length of plumule between the two treatments (with and without aging); only showed reduction in germination.

As for the size and weight of the seed, there is controversy of the effect of this attribute on the germination and vigor; this is based on evidence establishing that large and heavy seeds are more vigorous. Large and heavy seeds have advantages in the germination and emergence process compared with 
hectolítrico y mayor peso de mil semillas, lo que se reflejó en la germinación, longitud de plúmula y peso seco de plántula, dicho comportamiento fue similar al obtenido por Guberar y Banaj (1999).

Cuando las variedades fueron sometidas al tratamiento de envejecimiento acelerado, no mostraron un comportamiento uniforme, cada genotipo respondió de manera diferente, debido al estrés al que fueron sometidas, pero todas superaron aChihuahua en la expresión del número deplántulas normales, porcentaje de viabilidad y longitud de plúmula.

\section{Conclusiones}

Las fechas de siembra, variedades y densidades, tuvieron influencia en la productividad y en la calidad física de la semilla. La calidad fisiológica está condicionada por la constitución genética de los genotipos.

Las variedadesmenosafectadas porlapruebadeenvejecimiento acelerado fueron Menonita, Obsidiana y Karma, las cuales superaron a Chihuahua, en la expresión de las variables: porcentaje de germinación y longitud de plúmula.

La mayor producción de semillas fue obtenida en la fecha de siembra del 31 de diciembre, con $90 \mathrm{~kg}$ de semilla ha ${ }^{-1} \mathrm{y}$ la variedad obsidiana.

\section{Literatura citada}

Ayala, G. O. J.; Pichardo, G. J. M.; Estrada, G. J. A.; Carrillo, S. J. A. y Hernández, L. A. 2006. Rendimiento y calidad de semilla de frijol ayocote en el Valle del México. Agric. Téc. Méx. 32(3):313-321.

Berti, D. M.; Wilckens, E. R.; Hevia, H. F. y Montecinos, L. A. 2003. Influencia de la fecha de siembra y de la procedencia de la semilla en el rendimiento de capítulos de Calendula officinalis L., durante dos temporadas en Chillán. Agric. Téc. 63(1):3-9.

Braga, S. L.O.; Nedel, J. L.; Neto de Assis, F. y De Souza, M. M. 2000. Vigor de sementes e análise de crescimento de aveia preta. Scientia Agrícola. 57(2):305-312.

Ceccon, G.; Grassi, F. H. e Bicudo, S. J. 2004. Rendimiento de graos de aveia branca (Avena sativa L.) em densidades de planta e doses de nitrogenio. Ciencia Rural. Santa María Brasil. 34(6):1723-1729.

Forsberg, R. A. and Reeves, L. D. 1995. Agronomy of oats. In: the oat crop. (Ed.). Welch, R. W. $2^{\text {th }}$ (Ed.). Chaoman and Hall. Great Britain. 584:223-244. smaller seeds; larger seeds develop greater plumule and root due to a bigger endosperm and increased amount of nutrients. In this research was observed that the variety with a consistent behavior between the physical and physiological quality was shown by Obsidian with a good hectoliter weight and increased thousand kernel weights, which was reflected in germination, length of plumule and dry weight of seedling, such behavior was similar to that obtained by Guberar and Banaj (1999).

When varieties were subjected to accelerated aging treatment, did not show a uniform behavior, each genotype responded differently, because of the stress to which they were subjected, but all excelled Chihuahua in the expression of normal seedlings number, viability percentage and length of plumule.

\section{Conclusions}

Planting dates, varieties and densities, influenced the productivity and the physical quality of the seed. Physiological quality is determined by the genetic constitution of genotypes.

The varieties least affected by the accelerated aging test were Menonita, Obsidian and Karma, which outperformed Chihuahua, in the expression of the variables: percentage of germination and length of plumule.

The higher seed production was obtained in the planting date December 31, with $90 \mathrm{~kg}$ seed ha-1 and variety obsidian.

\section{End of the English version}

García, R. J. J.; Gámez, V. F. P.; Medina, C. T.; Gámez, V. A. J. y Espitia, R. E. 2008. Guía para producir semilla de avena en el Bajío. Desplegable para Productores Núm. 9. INIFAP-Fundación Produce Guanajuato.

Guberac, J. V. and Banaj, D. 1999. Influence of cereal seed size on shoot and root length. Die Bodenkultur. 50(1):39-43.

Gutiérrez-García, A. S.; Carballo-Carballo, A.; Mejía-Contreras, J. A.; Vargas-Hernández, M.; Trethowan, R. y Villaseñor-Mir, H. E. 2006. Caracterización de trigos harineros mediante parámetros de calidad física y fisiológica de la semilla. Agric. Téc. Méx. 32(1):45-55.

Ireta, M. J.; Medina, O. S. y Flores, L. H. E. 2007. Efecto de la fecha de siembra sobre las variedades de trigo en la Ciénega de Chapala. In: Memoria de la Segunda Reunión Nacional de Innovación Agrícola y Forestal-INIFAP. Guadalajara, Jalisco, México. 155 p. 
International Seed Testing Association (ISTA). 2004. International rules for seed testing. Switzerland. $72 \mathrm{pp}$.

Jiménez, G. C. A. 1992. Descripción de variedades de avena cultivadas en México. Secretaría de Agricultura y Recursos Hidráulicos (SARH). Instituto Nacional de Investigaciones Agrícolas (INIA). Centro de Investigaciones Agrícolas de la Mesa Central, Campo Agrícola Experimental Valle de México. Chapingo, Estado de México, México. Folleto técnico Núm. 3. 69 p.

Kiliç, H. and Gürsoy, S. 2010. Effect of seeding rate on yield and yield components of durum wheat cultivars in cotton-wheat cropping system. Sci. Res. Essays. 5(15):2078-2084. Available online at http://www.academicjournals.org/SRE.

Leyva, M. S. G.; Espitia, R. E.; Villaseñor, M. H. E. y Huerta, E. J. 2004. Pérdidas ocasionadas por Puccinia graminis f. sp. avenae Eriks. y Henn., causante de la roya del tallo en seis cultivares de avena (Avena sativa L.) en los Valles Altos de México. Rev. Mex. Fitopatol. 22(2):166-171.

Limón, O.A.; Villaseñor, M. E. y Espitia, R. E. 2010. Estrategias de manejo para la producción de avena forrajera y grano. INIFAP. CIRCE. CEVAMEX. Folleto técnico Núm. 39. 20 pp.

López, C. M. L.; Solano, H. S. y Zamora, D. M. 2008. Efecto de las fechas de siembra en los componentes de rendimiento de cebada maltera (Hordeum vulgare L.) bajo condiciones de riego. In: Memoria de la Tercera Reunión Nacional de Innovación Agrícola y Forestal. INIFAP. Yucatán, México. 321 p.

Medina, C. T.; García, R. J. J.; Gámez, V.F. P.; Gámez, V.A. J.; Bobadilla, M. M.; Hernández, C. R. E.; Dorantes, G. J. R. A; Ávila, P. M. A.; Espitia, R. E. y Buenrostro, F. 2009. Efecto de la fecha de siembra, genotipo, fertilización y densidad en la emergencia, número de panículas y rendimiento de semilla de avena. In: Memoria del III Foro Internacional Biológico Agropecuario. Tuxpan, Veracruz, México.

Rivera-Reyes, J. G.; Cortez-Baheza, E.; Peraza-Luna, F. A.; SerratosArévalo, J. C.; Posos-Ponce, P.; Guevara-González, P.; TorresPacheco, I. and Guzmán-Maldonado, S. H. 2008. Agronomic traits associated to yield and quality in oat seeds. Asian J. Plant Sci. 7(8):767-770

Statistical Analysis System (SAS). 2003. SAS on line Doc. Versión 9.1. Institute, Inc. Cary, NC, USA.
Sistema de Información Agrícola y Pecuaria (SIAP). 2010. Resumen nacional de avances agrícolas por estado. Producción anual. Cierre de la producción agrícola por cultivo. www.siap.gob.mx.

Solís, M. E.; Ramírez, R. A.; Aguilar, A. J. L. y De la Cruz, M. M. L. 2008. Efecto del ambiente sobre las características fisiológicas del trigo en el Bajío. In: Memoria de la Tercera Reunión Nacional de InnovaciónAgrícolay Forestal-INIFAP. Yucatán, México.322p.

Solís, M. E.; Ríos, R. S. A.; García, N. H.; Arévalo, V. A.; Grageda, C. O. A.; Vuelvas, C. M. A.; Días de León, T. G. J.; Aguilar, A. J. L.; Ramírez, R. A.; Narro, S. J.; Bujanos, M. R.; Marín, J. A. y Peña, M. R. 2007. Producción de trigo de riego en el Bajío. INIFAP, Campo Experimental Bajío. Celaya, Guanajuato, México. Folleto técnico Núm. 3.94 p.

Turk, M.A.; Rahman, M.;Al-Tawaha, A.; Nikus, O. and Rifaee, M. 2003. Response of six-row barley to seeding sate with or without Ethrel spray in the absence of moisture stress. International Journal of Agriculture \& Biology. Department of Plant Production. Faculty of Agriculture. Jordan University of Science and Technology (JUST). Irbid, Jorda. 5(4):416-418.

Valenzuela, P. A.; Martínez, B. A.; Medina, V. A. y García, M. L. 1995. Producción de semillas de trigo en el Valle de Mexicali, B. C. y San Luis Río Colorado, Sonora. INIFAP, CIRNO-CEMEXI. Folleto técnico Núm. 8. 40 pp.

Villaseñor, M. H. E.; Espitia, R. E. y Huerta, E. J. 2003. El Campo Experimental Valle de México, estratégico en la producción nacional de avena: Historia y Aportaciones. In: 60 años de investigación en el Campo Experimental Valle de México. Secretaría de Agricultura, Ganadería, Pesca y Alimentación (SAGARPA), Instituto Nacional de Investigaciones, Forestales, Agrícolas y Pecuarias (INIFAP), Centro de Investigación del Centro, Campo Experimental Valle de México. Chapingo, Estado de México, México. Publicación especial Núm.1. 17-30 pp.

Villaseñor,M.H.E.; Limón, O.A.; Huerta,E.J.;Rodríguez, G. M.F.;Espitia, R. E. y Leyva, M. S. G. 2008. El cultivo de avena en el Estado de México. Instituto Nacional de Investigaciones Forestales, Agrícolas y Pecuarias. Centro de Investigación Regional del Centro. Campo Experimental Valle del México. Chapingo, Estado de México, México. Folleto técnico Núm. 29.21 p. 